\title{
The Responsibilities and Opportunities of an Agricultural Library in Wartime
}

Mr. Kellar's paper was the third of three given before the Agricultural Libraries Section of the A.C.R.L., June 24, 1942.

Aricultural libraries in the 1 United States are of various kinds. The most important, both for size and content, is the United States Department of Agriculture Library in Washington, D.C. Largest in number and somewhat similar in type are the several libraries connected with the state colleges of agriculture. Special agricultural libraries are associated with museums, implement companies, flour milling concerns, meat processing corporations, and so forth. There are a few private reference institutions, such as the McCormick Historical Association. Many reference libraries of public character, both general and technical in nature, for example, the Library of Congress and the John Crerar Library of Chicago, have considerable holdings of agricultural interest. College, university, historical society libraries, and other institutions, containing extensive printed and manuscript collections, frequently possess important agricultural material. Agriculture, both as an occupation and a way of life, has an ancient lineage. Because of this there is hardly an institution in the country which does not offer, somewhere in its files, information of pertinence to the subject.
The following discussion is mainly concerned with libraries which are primarily of an agricultural character. Certain of the ideas may prove of interest to institutions which have agricultural material.

\section{Objective}

The geographical location of the various agricultural college libraries makes it possible for each to function for a definite area-the state. In the same sense the United States Department of Agriculture Library in Washington has for its province the nation as a whole and, where it is important to the United States, the agriculture of other countries as well. Similarly the libraries connected with the recently established agricultural laboratories in various regions of the United States should be chiefly interested in those areas. The field service libraries set up by the United States Department of Agriculture Library are concerned with the requests of research workers in their regions. Libraries devoted to specialties naturally have the nation or the world as their territory. In each instance, according to type and character, the agricultural library should endeavor to service the needs of its area or field to the best of its capacity. In wartime its operation should be directed to rendering special services to the war effort in every way 
conceivable, even though this may mean a considerable readjustment of customary activities.

\section{Collection of Agricultural Material ${ }^{1}$}

To operate efficiently an agricultural library should have as complete a collection of library materials relating to its fields of interest as it is possible to assemble. The many-sided relationship of agriculture to civilization necessitates a variety of sources of information. Among these should be noted certain physical objects such as wearing apparel used by the farmer and his family and workmen. The equipment of the main house, tenant homes, and other buildings on the farm should also be represented. This last group should be supplemented by plans and drawings of structures and where practicable scale models of interiors and exteriors of buildings. Plats of land holdings, charts and maps showing land use, rotation of crops, and similar data would likewise be valuable. The implements and machines used on the farm are important. These should include not only well-known and widely used items but local unpatented devices, products of the ingenuity of the individual, which are only found in a particular locality. In like fashion the civilization of the locality should be preserved. For this purpose the librarian should collect every type of physical article representing the country store, the school, the church, the mill, the creamery, the cheese factory, the cotton gin, and other centers of the community life of the farmer. Again drawings and models would be useful additions.

Since considerations of bulk and storage

1 Everett E. Edwards, of the Bureau of Agricultural Economics of the United States Department of Agriculture, has recently compiled an excellent of Agriculture, has recently compiled an excellent summary and analysis of various types of materials which should be collected, entitled "Objectives and
Needs for a National Agricultural History Research Center." often make difficult the collection and preservation of original, full-sized physical objects, these should be supplemented with a variety of pictorial records, such as photographs and moving picture films of activities upon the farm and in the locality, which are of agricultural significance. Dioramas often synthesize, visualize, and give life and meaning to farm operations in a way that cannot be accomplished by the display of single items. The picture as a whole binds things together to tell a story. Dioramas, even though necessarily reduced in size from that of the original, are decidedly effective and attract much interest. If moving parts are introduced into the scene, the effect is further heightened.

Manuscript materials, except in the case of a few institutions, have not been generally collected and preserved by agricultural libraries. Opportunities in this direction are intriguing. Of prime nature are the records which the farmer or members of his family have kept. Essential among these are diaries, account books, letters, notebooks, memoirs, and reminiscences. In this connection special attention should be given to the accounting necessitated by the direct relation of government to the farmer in recent years, especially crop and livestock data and income tax statements.

\section{Manuscript Records}

Supplementing this direct information about the farmer, and equally valuable, are the manuscript records of stores, mills, elevators, stockyards, tobacco warehouses, creameries, cheese factories, transportation companies, cotton gins, sugar beet and sugar cane refineries, implement and machinery companies and agencies, cooperative stores, and like enterprises. Another 
type of record relates to organizations with which the farmer is associated. Manuscripts of local agricultural societies, of the chapters of national bodies, and of religious, political, and social organizations in the rural community offer information of great value.

In a larger sense the farmer has been influenced by emigration, land policies, methods of land holding, availability of capital, supply and quality of labor, economic depressions, wars, equipment needed for farm life, transportation, marketing, religious and political movements, and the distribution of knowledge designed to stimulate better farming and to improve life in the country. Manuscript records relating to any of these subjects are of interest to an agricultural library. In particular may be noted the business records of land companies and land speculators and of railroads receiving land grants. Information pertaining to the invention, development, manufacture, and use of implements and machines, and data concerning marketing organizations is also of value. Records of firms processing agricultural products and of gas, electric power, and oil companies operating in rural districts are likewise of pertinence. Also indispensable are manuscripts of agricultural leaders, societies, and fairs, farm journals, and agricultural schools.

Archives of counties, cities, states, and the Federal government often contain important information of agrarian interest. Since these cannot be collected by agricultural libraries, representatives of these institutions should make themselves familiar with the location and the nature of these records. The surveys of various types of such archives recently made by the Work Projects Administration, and especially the Historical Records Survey, will be found very useful in furnishing information concerning materials of this character. The guides to the manuscript collections in American libraries and surveys of church records, which the H.R.S. has prepared, reveal valuable agricultural material. Also the field notes and the published checklists of the American Imprints Inventory of the H.R.S. contain a vast amount of data concerning agricultural literature published in the various states prior to 1877 and in a few instances down to 1890 . Sets of all of these publications should be assembled if possible in agricultural libraries. If this is not practicable, nearby institutions which do have them should be located and an analysis made of the content of the survey records.

\section{Other Printed Materials}

Printed materials which should be assembled, in addition to state and Federal governmental reports and publications, comprise articles, books, pamphlets, circulars, broadsides, maps, charts, statistics, periodicals, and newspapers relating to agriculture. Of particular interest are rural newspapers and city newspapers with sections devoted to rural activities. The literature of travel should be included and also trade journals, publications of nursery and seed companies, implement machinery concerns, mail-order houses, and public utility corporations.

If possible originals of all the types of material cited above should be obtained. When this cannot be done, photostatic, microfilm, microprint, and other types of copies should be secured.

Every agricultural library has material, to a greater or less degree, relating to the agriculture of foreign countries. In view of the development of international relations and the interplay of economic and 
social forces throughout the world, it will be necessary for agricultural libraries in this country in the future to have much more information than formerly about agriculture abroad. Inasmuch as no one institution could expect to assemble adequate information about all countries, it is suggested that the agricultural libraries of the United States cooperate in working out a plan whereby individual institutions will assume responsibility for gathering records about individual countries. To offer a concrete example a good beginning could be made at the present time by bringing together in one place all the agricultural data about a given foreign country which can be found within the United States and in allied or neutral nations. In the postwar period further information could be obtained. This would necessitate the securing of duplicate original records from other depositories and liberal use of microfilm and other copying methods. In this way there would eventually be at least one American library which would have the necessary material relating to any country concerning which data was desired. Because of the general character of the United States Department of Agriculture Library, it possibly would be fair to ask this institution to take the leadership and to make itself responsible for assembling definitive material about one or two of the most important foreign countries, for example, Great Britain and Russia, and perhaps any others for which arrangement could not be made elsewhere.

In view of the importance of transportation in connection with the life and activities of rural communities, agricultural libraries should endeavor to assemble good collections of material relating to all kinds of transportation. One of the main problems in the agriculture of today is distri- bution of commodities, and transportation plays a chief role in this problem. Add to this the rubber shortage and increased demands on railroads, internal navigation, and airlines, and you have scope for assembling valuable and unique collections of material relating to a subject vital to agriculturists. Aeronautics should not be neglected in this connection because of the possibilities of the movement of heavy freight, particularly perishable products, in huge transport planes in the near future. Out of such a collection experts can find ideas for facilitating the movement of farm produce in certain sections which may prove applicable to the country as a whole and eventually help in solving maldistribution.

These libraries should also have adequate data concerning the various fields in the physical sciences and, to round out the picture of civilization, records in due proportion pertaining to the arts, literature, history, law, and other branches of knowledge.

One agricultural library in each state should assume the responsibility for making a special collection of material relating to the agricultural activity of the state in connection with the present war, with a view to preserving and arranging and making this data available for research and publication in the postwar period.

If an adequate agricultural history of a state has not been written, one library should assemble materials dealing with the subject and otherwise stimulate acquisition and research so that eventually a good history can be prepared and published.

As an example of what can be done in collecting special types of material of importance for agriculture, Thomas D. Clark, of the University of Kentucky at Lexington, has gathered several truck 
loads of records of country storekeepers, taken from Kentucky, Tennessee, and other Southern states. Lewis Atherton, of the University of Missouri at Columbia, interested in the same subject, has amassed similar records from Missouri, the Southwest, and also several Southern states. For several years Charles $M$. Thompson, of the University of Illinois, has been assembling a wide variety of ephemeral material of the present time and also older records of a type not always preserved, much of which is of agricultural interest. These include mill records, papers of implement and machinery concerns, mailorder houses, public utility companies, and like data. In bulk this collection now numbers several million items.

The national Committee on Conservation of Cultural Resources, which stems from the National Resources Planning Board, has set up state committees to arrange for the protection of all types of cultural materials, including museum items, and it is assumed that the agricultural libraries are working with it for the protection of their own records. In addition the national committee is interested in establishing further state committees to collect and preserve data relating to the present war. Publication of a manual to aid local and state collecting is contemplated as one of the first steps in this direction. Being largely ephemeral, the collection of these records should not be put off, for experience with the documents of the last World War proves conclusively that if immediate steps are not taken to preserve materials of this type, when they are wanted later they will not be available. The Society of American Archivists and the American Association for State and Local History are cooperating with the Committee on Conservation of Cultural
Resources in these activities. Naturally much of the material which will be assembled will be of agricultural importance and institutions interested in this and other subjects should freely aid in these undertakings.

The Committee on Microcopying Materials for Research of the American Council of Learned Societies has been engaged since January I94I in making microfilm copies of important manuscript and printed source materials in depositories in England and transferring the negatives to the Library of Congress where copies may be obtained at cost, plus a small service charge. These films have much of interest to agricultural libraries and they should take advantage of the opportunity to secure such data for their files. As an indication of the scope of the documents chosen for copying, the priorities established by the subcommittee on selection are first, material relating to America, second, that pertaining to England in all periods, and third, records concerning other countries deposited in England. If the program should eventually be extended to libraries in other foreign countries, additional material of agricultural interest will be available.

\section{State Agricultural Museums}

In the last few years the Agricultural History Society has gone on record as favoring the establishment in Washington of a national agricultural museum, comparable to the Smithsonian Institution for science. The plan worked out by a committee of the society includes the creation of branch museums which would illustrate the character and development of agriculture in a region or state. An opportunity here exists for a number of agricultural libraries to undertake the sponsor- 
ship for such museums for their particular areas. Practical examples would be to restore as an actual operating unit, a cotton, rice, tobacco, or sugar plantation of the ante-bellum period; a Wisconsin, Michigan, or Pacific Northwest lumber camp, a bonanza wheat farm, and a Western cattle ranch of the seventies, or a California or Florida fruit ranch of a more modern period. Working exhibits of this type, which in certain instances could be based on original sites and holdings, would attract widespread public interest in our agricultural evolution, and the fees charged for admission to these plantations or farms would take care of maintenance and perhaps even produce a revenue. It is probable that the Division of Historic Sites of the National Park Service would be glad to cooperate in the setting up of such agricultural memorials. Outdoor museums of this character located strategically throughout the United States would serve to build up public morale and pride in agriculture both in the war period and subsequently and would provide education for thousands who visited them, particularly children.

\section{Processing}

A national union catalog of agricultural materials or a selective union catalog of this nature should be compiled by the Library of the United States Department of Agriculture, containing a description and the depository location of important agricultural records, both printed and manuscript. Eventually this should cover documents in foreign countries as well as the United States. Contributions to this catalog could be made not only by the Federal library but also by other agricultural institutions in this country. The central file should be in the department library in Washington. The already widespread bibliographical activities of the United States Department of Agriculture Library should be continued and expanded so as to eventually provide national and international control of the literature of agriculture.

In normal times the problem of bringing material collected under control by physical arrangement and cataloging should be actively and continuously carried on, but in the war period this routine should be changed. Attention to usual cataloging should now be reduced to the most simple forms to allow members of the staff to give time to other special types of processing needed for war activities.

\section{Informational Services}

In every one of the areas served by agricultural libraries, because of the war there will be special defense activities in progress, which are superimposed upon the regular life of the people; for example, the influx into rural districts of large groups of population of urban origin associated with emergency operations. There are important services which can be rendered to those concerned with these activities, in addition to offering customary assistance to the agricultural community.

Institutions can answer questions and furnish data about rural housing and sanitation, nutrition, first aid and home nursing, gardening and farming, implements and machinery, electrification, and technical matters needed for research. They can also obtain books not in the agricultural field through interlibrary loans or secure copies of records from other institutions.

To serve all classes in the area special indexes should be made of certain types of 
current agricultural literature, such as books and pamphlets, government reports, documents of organizations and learned societies, articles in popular magazines, farm journals, publications of business houses, trade journals, and the like, which are not only of agricultural interest for research workers and others in the community but also contribute to the development of the war effort. In addition to calling attention of individuals interested to the existence of these indexes, subject bibliographies, based on the indexes, should be prepared. These should be mimeographed and at regular intervals distributed where needed. The library should offer to obtain originals or copies of material listed in the indexes and bibliographies which it does not have in its own possession.

Subscriptions should be made to clipping services in order to secure items from several nationally known newspapers on matters of agricultural interest relating to the war. In addition the more important local newspapers should likewise be clipped by members of the staff for similar information. All of these articles should be mounted, arranged, and indexed by subject, and both indexes and originals made available to individuals in the community who should have the information they contain.

Members of the library staff should prepare, publish, and distribute mimeographed bulletins from time to time, about articles in current periodicals and newspapers pertaining to national defense which are of interest to the agricultural community. In these bulletins should also be published special bibliographies on agricultural topics, assembled by members of the library, with the announcement that copies of any material listed could be supplied by the library to the public at reasonable cost. One or more articles should also be reprinted in full in each issue of the bulletin.

Agricultural libraries should arrange for a series of speeches or lectures upon various topics connected with the function of agriculture in the war effort. Speakers should be chosen from government officials connected with agrarian activities, faculty members of colleges and universities, leaders of farm organizations, members of the staff, and others qualified for this purpose. These speeches should later be published in mimeographed form and distributed to those interested.

Arrangements should be made with local radio stations to give a series of programs directed particularly to the interests of the area. These programs should.contain information respecting the part of farming in the war and also data of nonagricultural character pertaining to other phases of the emergency.

Representatives of the staff should attend and take an active part in meetings held in connection with defense work. Where desired the library should furnish speakers for such meetings.

The libraries of the state colleges of agriculture should establish closer relations with the county agricultural agents who furnish information about farming and farm life directly to the farmer. It is estimated that at present about a fifth of the fifty or more bulletins which county agents annually distribute in each community originate in the United States Department of Agriculture and the remainder are largely the product of the state colleges of agriculture. The latter are written for use in the various sections of a state and take into consideration local conditions. The Federal literature is usually prepared 
for national or regional use and does not always have special adaptation for a locality. Representatives of state colleges of agriculture, acting in conjunction with county agents, should modify, change, or add new material as required to the content of the bulletins of the United States Department of Agriculture in order to make them apply more particularly to the various sections of a state and thus make them more useful. Once the necessary information has been obtained members of the staff of the state agricultural library could assist with the necessary editing. The revised bulletins could then be mimeographed to lessen the cost and sent to the county agent for distribution. In addition the staffs of agricultural libraries might prepare "dodgers" or leaflets containing special information furnished by county agents which the latter wished to place in the hands of the farmer. Attention should be directed, among other things, to the education of women and children in the operation and maintenance of farm implements and machines. Special tractor schools, a number of which have been established by farm implement companies, have already provided training for women in operating these machines. Agricultural libraries could supply literature for such schools and generally furnish information to women on the farm about farm implements and machines and other subjects which are of interest in aiding the war effort. Such institutions should also endeavor to service, where this is not already being done, the agriculture literature needs of county agents and of the 4- $\mathrm{H}$ clubs and other farm organizations.

\section{Library Cooperation}

Agricultural libraries, in order to carry out activities already indicated, should cooperate with other agricultural institutions in interlibrary lending, collection and dissemination of information, and in other projects designed to stimulate agriculture to contribute its share to the winning of the war and to acquaint the farmers with what is going on outside of their own communities. They should also cooperate with other institutions in their localities in projects which will increase their efficiency as libraries and aid in other aspects of the emergency.

The agricultural libraries of the country are among the most efficiently operated of American institutions. Individually and as a group they are already participating in various ways in the war effort. The importance of agriculture in the world today creates an incentive and a responsibility which will keep agricultural librarians on the alert now and in the future. 